\title{
Microscopic Characterization of Croton cordiifolius Baill. (Euphorbiaceae)
}

\author{
lasmine Andreza Basilio dos Santos Alves', Rafaela Damasceno Sá2, Marília Barbosa Cadena², Rafael Matos Ximenes', Karina Perrelli \\ Randau $^{2^{*}}$
}

\section{lasmine Andreza Basilio dos Santos Alves', Rafaela Damasce- no Sá2, Marília Barbosa Cadena², Rafael Matos Ximenes ${ }^{1}$, Karina Perrelli Randau2* \\ 'Laboratório de Etnofarmacologia, Departamento de Antibióticos, Universidade Federal de Pernambuco, Avenida Professor Arthur de Sá, Cidade Universitária, Recife, PE, BRAZIL. \\ 2Laboratório de Farmacognosia, Depar- tamento de Ciências Farmacêuticas, Universidade Federal de Pernambuco, Avenida Professor Arthur de Sá, Cidade Universitária, Recife, PE, BRAZIL.}

\section{Correspondence}

Karina Perrelli Randau,

Departamento de Ciências Farmacêuticas, Laboratório de Farmacognosia, Av. Prof. Arthur de Sá S/N, CDU, Recife-PE, BRAZIL. CEP:50740-521.

Phone no: +5581988225279

E-mail: krandau@hotmail.com

History

- Submission Date: 22-12-16

- Review completed: 05-01-17;

- Accepted Date: 02-02-17.

DOI : 10.5530/pj.2017.3.61

Article Available online

http://www.phcogi.com/v9/i3

\section{Copyright}

(C) 2017 Phcog.Net. This is an openaccess article distributed under the terms of the Creative Commons Attribution 4.0 International license.

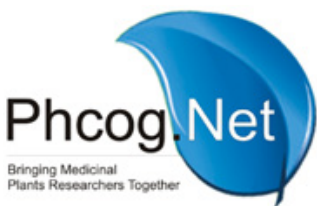

\begin{abstract}
Background: Croton cordiifolius Baill. is popularly known as "quebra-faca" in the Brazilian Northeast and is used to treat general inflammation, pain, and gastrointestinal disturbances. Objective: This paper aims to study the anatomical characteristics of $C$. cordiifolius. Materials and Methods: Cross-sections and paradermic sections of root, stem, petiole and leaf blade were obtained by hand and submitted to double staining with astra blue and safranin process for the anatomical study. Maceration was performed according to the method of Jeffrey. Results: The secondary root has peridermis, parenchymatic cortex, collateral vascular system surrounded by sclerenchyma. The secondary stem has peridermis, cortical region with lignified cells, isolated groups of fibers, laticifers, prismatic crystals, druses and starch. The vascular system of the stem is bicollateral. The petiole and the leaf blade have stellate, simple and glandular trichomes. The leaf blade is hypostomatic, with paracytic stomata. The mesophyll is isobilateral and the midrib shows a concave-convex contour. Laticifers occur in stem, petiole and leaf blade. Prismatic crystals and druses are found in all organs analysed. Through the maceration it was possible to identify the type of vessel elements. Conclusion: The anatomical features are useful for differentiation of other species of Croton and provide support to their quality control.
\end{abstract}

Key words: Croton cordiifolius, Euphorbiaceae, Pharmacobotany, Plant anatomy, Quebra-faca

\section{INTRODUCTION}

Caatinga ecosystem, covering almost one million $\mathrm{km}^{2}$ in Brazilian Northeast, is characterized by xerophytic vegetation affected by long and irregular drought, high temperatures and elevated ultraviolet radiation. It is an exclusively Brazilian biome and its plants are widely used in folk medicine of local communities, whose socio-demographic conditions favor this reality. ${ }^{1-2}$

Euphorbiaceae family includes about 300 genera and 7600 species, including trees, shrubs, herbs and creepers. ${ }^{3}$ This family is, quantitatively, the second most representative of Brazilian Caatinga, with about 68 species of Croton genus. ${ }^{4}$ This genus, which presents a high pattern of species diversity and is the second largest in Euphorbiaceae family, consists of about 1200 species, of which 350 are present in Brazil. $^{4-5}$ It is considered of difficult taxonomic classification due to the high number of species, problems with the nomenclature, polymorphism and specific delimitation of its representatives. ${ }^{6}$

Traditional uses of Croton spp. have often been confirmed by pharmacological tests. In Brazil, among Euphorbiaceae Family members, this genus has the highest number of ethnopharmacological uses, followed by Euphorbia and Jatropha. ${ }^{7}$ Among the proven pharmacological activities can be highlighted antioxidant, ${ }^{2,8}$ anti-inflammatory and anti-nociceptive, ${ }^{9}$ leishmanicidal, ${ }^{10}$ antidiarrheal, ${ }^{11}$ antiulcer, ${ }^{12}$ anti-ath- erogenic and anti-ischemic, ${ }^{13}$ cytotoxic, antimicrobial, antiviral, antihyperlipidemic, antidiabetic and weight loss actions. ${ }^{14-17}$

Due to the chemical compounds already described for many Croton species, such as mono and sesquiterpenes, diterpenoids, flavonoids, tannins and alkaloids, it can be characterized as a promising source of bioactive molecules and as a remarkable potential for research. ${ }^{18}$ The growing interest in studying the various species of the Croton genus has resulted in the isolation and identification of more than $100 \mathrm{com}$ pounds currently known in Brazil. ${ }^{19}$

Croton cordiifolius, popularly known as "quebra-faca" in the Brazilian Northeast, is used to treat general inflammation, pain, and gastrointestinal disturbances. ${ }^{20-21}$ Nogueira and collaborators ${ }^{22}$ described the antinociceptive activity and chemical composition of its leaf's essential oil.

Although the Croton genus is widely studied, including some species found in the semi-arid northeast, no studies characterizing the botany of $C$. cordiifolius have been published. Since the correct species identification is a relevant step for researches reproducibility and the standardization of morphoanatomic markers is one of the parameters required for quality control of herbal raw material or drugs, this paper aims to study the anatomical characteristics of the root, stem, petiole and leaf blade of $C$. cordiifolius. 


\section{MATERIALS AND METHODS}

\section{Plant material}

Adult specimens of Croton cordiifolius were collected in the city of Salgueiro, Pernambuco, Brazil. The voucher specimen was deposited in the Herbarium Dárdano de Andrade Lima, of the Instituto Agronômico de Pernambuco (IPA), under registration number 89211.

\section{Anatomical characterization}

Several individuals of the same species were used to conduct this study. Various cross-sections at the middle region of the root, stem, petiole and leaf blade fixed in FAA 50\% were obtained by freehand, ${ }^{23}$ using a common razor blade. For leaf blade were also performed paradermal sections. All sections were clarified in sodium hypochlorite solution $(50 \%)^{24}$ and were stained according to the technique described by Bukatsch, ${ }^{25}$ with safranin and astra blue. Then, semipermanent histological slides were prepared containing the sections botanical material, following common plant anatomy procedures. ${ }^{23,26}$ The maceration was performed according to the method of Jeffrey, ${ }^{23}$ using fragments of root, stem and leaf that were disintegrated with the mixture of $10 \%$ nitric acid and $10 \%$ chromic acid (1:1). The analysis of the semipermanent histological slides prepared were conducted with a light microscope (Alltion) equipped with a digital camera. ${ }^{27}$

\section{RESULTS}

\section{Anatomical characterization}

The secondary root, in cross-section, shows cylindrical contour, presenting peridermis (Figure 1A). The cortical region is composed of about seven layers of parenchymatic cells (Figure 1A), some of them containing starch (Figure 1B). The vascular system is formed by xylem occupying the central region of the root, and by phloem surrounding the xylem (Figure 1A). A continuous band of sclerenchyma delimits the vascular system (Figure 1A). Prismatic crystals and druses are displayed in the phloem, sclerenchyma and in the cells of the cortical region located near the sclerenchyma (Figure 1B).

The secondary stem, in cross-section, exhibits cylindrical contour and peridermis (Figure 1C). The cortical region is formed by parenchyma, where are found lignified cells (Figure 1C), isolated groups of fibers (Figure 1C), laticifers (Figure 1C), prismatic crystals (Figure 1D), druses (Figure 1D) and starch (Figure 1C,D). The prismatic crystals and druses are usually visualized near the sclerenchyma surrounding the vascular system and in the sclerenchyma itself (Figure 1D), as well as in the phloem and in the medullar region (Figure 1F). The prismatic crystals are more frequent than the druses. The phloem is situated externally to the xylem, forming a continuous ring, as well as internally the xylem, arranged in the form of isolated nuclei in the medullar region (Figure $1 \mathrm{E})$. In the internal phloem are present groups of isolated fibers (Figure $1 \mathrm{E})$. In the pith are found parenchyma (Figure 1E,F), lignified cells, stone cells, prismatic crystals, druses and starch (Figure $1 \mathrm{~F}$ ).

In cross-section, the petiole also presents cylindrical contour (Figure $1 G$ ). The epidermis is uniseriate, coated with a thin cuticle layer (Figure $1 G)$. There are non-glandular trichomes and glandular trichomes. The non-glandular trichomes can be of two types: stellate trichome with multicellular stalk (Figure 1H) and simple trichome (Figure 1I). The glandular trichome has a unicellular head (Figure 1J). In subepidermal position appears about four layers of collenchyma (Figure 1G). The central region of the petiole is filled by parenchyma, in which are inserted several col-

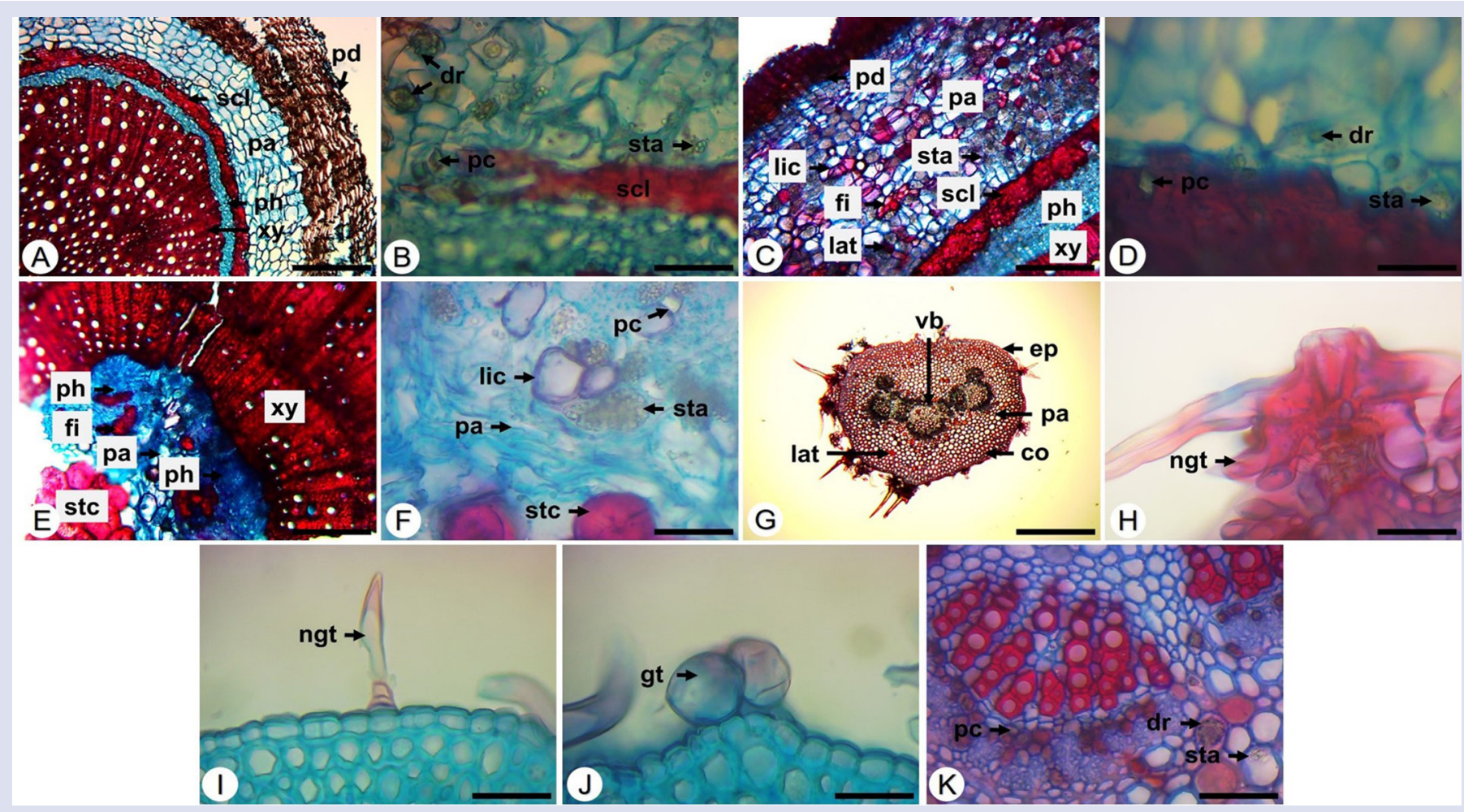

Figure 1: Cross-sections of the root, stem and petiole of Croton cordiifolius Baill.

Root: A. general view. B. crystals and starch. Stem: C. cortical region. D. crystals and starch. E,F. medullar region and vascular system. Petiole: G. general view. H. stellate trichome. I. simple trichome. J. glandular trichome. K. crystals and starch. co: collenchyma, dr: druse, ep: epidermis, fi: fiber, gt: glandular trichome, lat: laticifer, lic: lignified cell, ngt: non-glandular trichome, pa: parenchyma, pc: prismatic crystal, pd: peridermis, ph: phloem, scl: sclerenchyma,

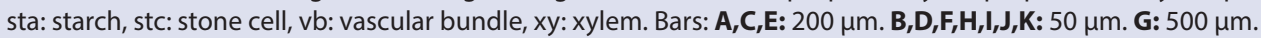



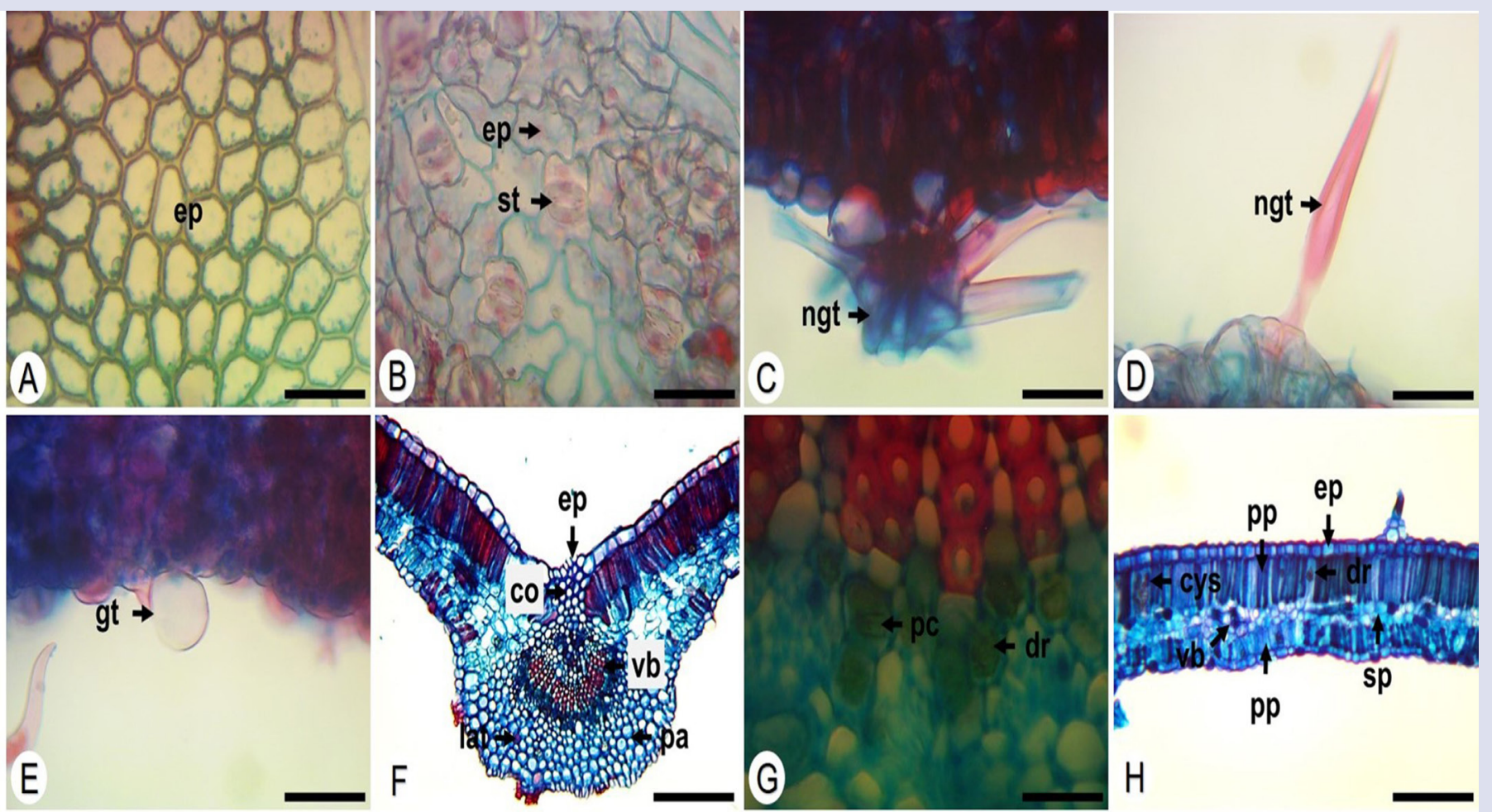

Figure 2: Cross-sections and paradermic sections of the leaf blade of Croton cordiifolius Baill.

A. adaxial face. B. abaxial face. C. non-glandular stellate trichome. D. non-glandular simple trichome. E. glandular trichome. F. midrib. G. crystals in the midrib. H. mesophyll. co: collenchyma, cys: cystolith, dr: druse, ep: epidermis, gt: glandular trichome, lat: laticifer, ngt: non-glandular trichome, pa: parenchyma,

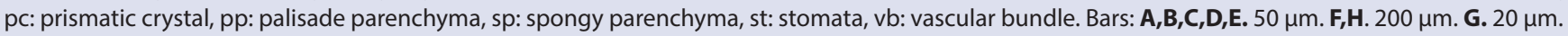

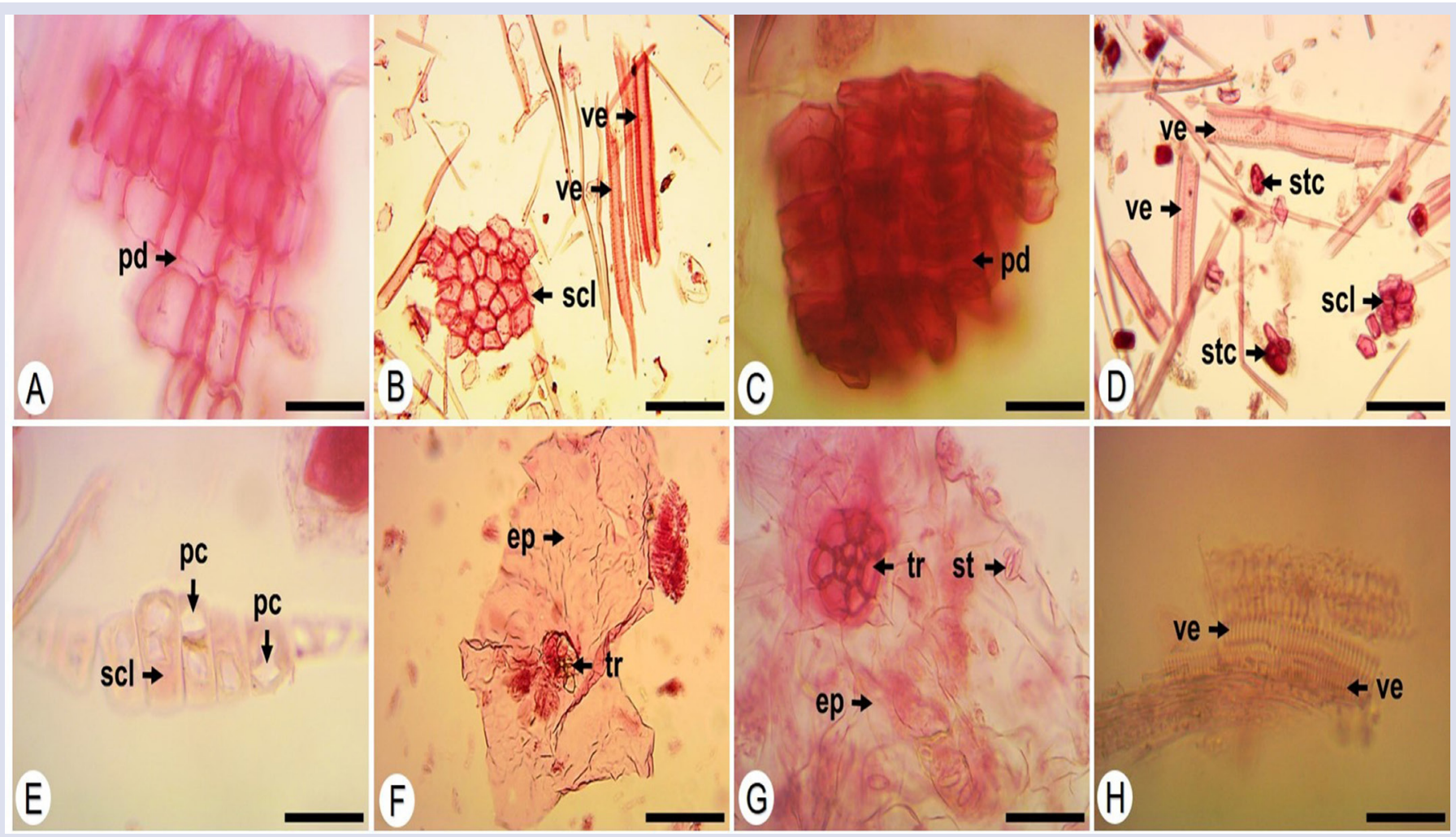

Figure 3: Maceration of the root, stem and leaf of Croton cordiifolius Baill.

A. peridermis of the root. B. parenchyma and vessel elements of the root. C. peridermis of the stem. D. parenchyma, stone cells and vessel elements of the stem. E. prismatic crystals in the sclerenchyma of the stem. F. adaxial face of the leaf blade. G. abaxial face of the leaf blade. $\mathbf{H}$. vessel elements of the leaf. ep: epidermis, pc: prismatic crystal, pd: peridermis, scl: sclerenchyma, st: stomata, stc: stone cell, tr: trichome, ve: vessel element. Bars: $\mathbf{A}, \mathbf{C , E}, \mathbf{G}, \mathbf{H} . \mathbf{5 0}$ $\mu \mathrm{m}$. B,D,F. $200 \mu \mathrm{m}$. 
lateral vascular bundles (Figure $1 G$ ). Next to the bundles are visualizated laticifers (Figure $1 \mathrm{G}$ ), prismatic crystals, druses and starch (Figure $1 \mathrm{~K}$ ). Different what occurs in the secondary stem, in the petiole the druses are more frequent than the prismatic crystals.

The leaf blade, in frontal view, has cells with straight or slightly sinuous walls on the adaxial face (Figure 2A) and cells of sinuous walls on the abaxial face (Figure 2B). The leaf blade is hypostomatic, with paracytic stomata (Figure 2B).

In cross-section, the leaf blade presents the same types of trichomes described for the petiole (Figure 2C,D,E). The midrib shows a concaveconvex contour (Figure 2F). The epidermis is composed of a single layer of cells and is covered by a thin cuticle (Figure $2 \mathrm{~F}$ ). The collenchyma is formed by about three to four layers, located in the adaxial face (Figure $2 \mathrm{~F})$. The vascular system is composed of a larger collateral vascular bundle towards to the abaxial face and smaller vascular collateral bundles towards the adaxial face (Figure $2 \mathrm{~F}$ ). Laticifers are presents in the parenchyma (Figure $2 \mathrm{~F}$ ). In the phloem are found prismatic crystals and druses (Figure 2G), being the druses more abundant, as occurs in the petiole. The druses can also be found in the parenchyma of the midrib, as well as in the mesophyll (Figure $2 \mathrm{H}$ ). The mesophyll is isobilateral, with a layer of palisade parenchyma facing each face of the epidermis and around two to three layers of spongy parenchyma between the palisade tissue (Figure 2H).

Through the maceration it was possible to verify some of the characters observed in the cross-sections and paradermic sections of the analyzed organs. In maceration of the root are observed fragments of peridermis (Figure 3A), sclerenchyma and vessel elements with alternating pits (Figure $3 \mathrm{~B}$ ). In the maceration of the stem are also observed fragments of peridermis (Figure 3C), sclerenchyma and vessel elements with alternating pits (Figure 3D), besides stone cells (Figure 3D) and sclerenchymatic tissue with prismatic crystals (Figure 3E). In the maceration of the leaf are found fragments of the adaxial face (Figure 3F) and abaxial face (Figure 3G), where in the latter the stomata are visualized. The stellate trichome or their stalk are identified in the fragments of epidermis (Figure 3F,G). The other trichomes are difficult to see in maceration. In the maceration of the leaf it is also seen that the vessel elements are of the helical type (Figure $3 \mathrm{H}$ ).

\section{DISCUSSION/ CONCLUSION}

\section{Anatomical characterization}

The laticifers are distributed in several genera of Euphorbiaceae ${ }^{28}$. They can be found in all vegetative organs, as in the case of species of Euphorbia. ${ }^{29}$ According to Rudall ${ }^{30}$ in Croton the laticifers are non-articulated and their abundance depends on the environment. Randau $e t a l^{31}$ did not mention the presence of laticifers in the roots of Croton rhamnifolius and C. rhamnifolioides, as it is also not identified in this study. Also as a common feature with both species of Croton analyzed by Randau et al, ${ }^{31}$ in C. cordiifolius is described a parenchymatic cortex in the root. However, in C. rhamnifolius were verified gelatinous fibers in the phloem and in C. rhamnifolioides was seen pericycle. None of these characteristics is present in C. cordiifolius.

The pericycle was also visualizated in the stem of $C$. rhamnifolioides. ${ }^{31}$ It is possible to distinguish the stem of the species of Croton by the type of tissue that forms the cortical region and the structures found in these tissues. In C. rhamnifolius the cortical region is composed by collenchyma and parenchyma, while in C. rhamnifolioides, C. draco and C. cordiifolius only parenchyma is found. ${ }^{31-32}$ However, in the cortical parenchyma of $C$. rhamnifolioides were observed fibers, laticifers and starch, ${ }^{31}$ while in the cortical parenchyma of $C$. draco were found crystals, ${ }^{32}$ besides the other mentioned elements for $C$. rhamnifolioides. In this study is also verified the presence of all these elements previously mentioned for the cortical region of the other species of Croton, however, it is also noted the presence of lignified cells.

Hayden and Hayden ${ }^{33}$ noted internal phloem in C. glandulosus, but did not mention the occurrence of fibers associated with the internal phloem, as occur in C. cordiifolius. In C. draco was reported the presence of fibers in the external phloem. ${ }^{32}$ Farías et al ${ }^{32}$ also observed crystals in the sclerenchyma. According to Franceschi and Nakata, ${ }^{34}$ the morphology of the crystals produced can be of a single type throughout the plant, or several types being each specific for a particular organ, or several types within the same organ. It was verified that this last case occurs in C. cordiifolius.

Tadavi and Bhadane ${ }^{35}$ investigated the anatomy of rachis, petiole and petiolule in 43 species and 20 genera of Euphorbiaceae and observed that the variation in the distribution of sclerenchyma, collenchyma and vascular patterns, besides the shapes observed in the transverse section, can be used for differentiation of the species. Sá-Haiad et al ${ }^{36}$ analyzed ten species of Croton. In three species, the outline of the petiole was circular; in six species the outline was approximately circular, with a depression in the adaxial face; and in one species the outline was concave-convex. Croton rhamnifolius and C. rhamnifolioides exhibit a plane-convex contour, ${ }^{31}$ differing from the contour displayed by C. cordiifolius. In addition, the species of Croton can also be differentiated by the types of trichomes that are present in the petiole. In C. rhamnifolius and C. rhamnifolioides were verified dendritic and glandular trichomes, ${ }^{31}$ in C. cajucara was identified the multiradiate trichome, ${ }^{37}$ while in C. cordiifolius is seen stellate, simple and glandular trichomes.

Lucena and Sales ${ }^{38}$ have characterized the types of trichomes presents in leaf blade of 14 species of Croton as stellate, fasciculate, multiradiate, dendritic, lepidote, simple and glandular. The authors have stated that the type of trichome is an important feature for the taxonomy of the genus. According to Haiad et $a l,{ }^{36}$ are common characters in leaf blades of Croton species: amphistomatic leaves, paracytic stomata, dorsiventral mesophyll and biconvex midrib, with collateral vascular bundles. Nevertheless, in C. cordiifolius the leaves are hypostomatic, the mesophyll is isobilateral and the midrib has a concave-convex contour. But, some of these characteristics of $C$. cordiifolius have already been described in other species of Croton, such as hypostomatic leaves in C. lanjouwensis ${ }^{39}$ and isobilateral mesophyll in C. rhamnifolioides. ${ }^{31}$ Croton rhamnifolius presents midrib with a plan-convex contour. ${ }^{31}$

No studies were found in the literature on the maceration of the organs of species of Croton. However, the studies of Luchi ${ }^{40}$ on the root of C. urucurana, Luchi ${ }^{41}$ on the stem of C. urucurana and Hayden and Hayden $^{33}$ about the stem of C. glandulosus described that the vessel elements have alternating pits.

The characters described in this study are important for the differentiation of C. cordiifolius from the other species of the genus Croton. Some characters, such as the non-glandular trichomes in the leaf blade, and the crystals, as the druses, demonstrate the adaptation of the species in xeric environments

\section{ACKNOWLEDGEMENT}

The authors thanks to CAPES and CNPQ for financial support in the form of fellowship awards.

\section{CONFLICT OF INTEREST}

None

\section{REFERENCES}

1. Roque AA, Rocha RM, Loiola MIB. Uso e diversidade de plantas medicinais da Caatinga na comunidade rural de Laginhas, Município de Caicó, Rio Grande 
do Norte (Nordeste do Brasil). Rev Bras PI Med 2010;12(1):31-42. https://doi. org/10.1590/S1516-05722010000100006.

2. Morais SM, Catunda-Júnior FEA, Silva ARA, Martins-Neto JS. Atividade antioxidante de óleos essenciais de Croton no Nordeste do Brasil. Quim Nova 2006;29(5):907-10. https://doi.org/10.1590/S0100-40422006000500004.

3. Cronquist A. An integrated system of classification of flowering plants. New York: Columbia University Press; 1981. PMid:6117027.

4. Costa-Filho LO, Silva MHM, Almeida-Cortez JS, Silva SI, Oliveira AFM. Foliar cuticular n-alkane of some Croton species from Brazilian semiarid vegetation. Biochem System Ecol 2012;41:13-5. https://doi.org/10.1016/j.bse.2011.11.005.

5. Silva JS, Sales MF, Gomes APS, Carneiro-Torres DS. Sinopse das espécies de Croton L. (Euphorbiaceae) no estado de Pernambuco, Brasil. Acta Bot Bras 2010;24(2):441-53. https://doi.org/10.1590/S0102-33062010000200015.

6. Webster GL. A provisional synopsis of the section of the genus Croton (Euphorbiaceae). Taxon 1993;42:793-823. https://doi.org/10.2307/1223265.

7. Trindade MJS, Lameira OA. Espécies úteis da família Euphorbiaceae no Brasil. Rev Cub Plantas Med 2014;19(4):1-17.

8. Shukla S, Mehta A, John J, Singh S, Mehta P, Vyas SP. Antioxidant activity and total phenolic content of ethanolic extract of Caesalpinia bonducella seeds. Food Chem Toxicol 2009;47(8):1848-51. https://doi.org/10.1016/j.fct.2009.04.040; PMid:19422871.

9. Rocha FF, Neves MN, Costa EA, Matos LG, Müller AH. Evaluation of antinociceptive and anti-inflamatory effects of Croton pullei var. glabrior Larnj. (Euphorbiaceae). Rev Bras Farmacogn 2008;18(3):344-9.

10. Lima GS, Castro-Pinto DB, Machado GC, Maciel MAM, Echevarria A. Antileishmanial activity and trypanothione reductase effects of terpenes from the Amazonian species Croton cajucara Benth (Euphorbiaceae). Phytomedicine 2015;22(12):1133-7. https://doi.org/10.1016/j.phymed.2015.08.012 ; PMid:26547537.

11. Silva ADS, Silva KM, Clementino Neto J, Costa VCO, Pessôa HLF, Tavares JF, Figure. Croton grewioides Baill. (Euphorbiaceae) shows antidiarrheal activity in mice. Phcog Res 2016;8(3):202-5. https://doi.org/10.4103/0974-8490.181465; PMid:27365990 PMCid:PMC4908850.

12. Leite GO, Penha ARS, Silva GQ, Colares AV, Rodrigues FFG, Costa JGM, et al. Gastroprotective effect of medicinal plants from Chapada do Araripe, Brazil. J Young Pharm 2009;1(1):54-6. https://doi.org/10.4103/0975-1483.51881.

13. Afriyie DK, Asare GA, Bugyei K, Asiedu-Gyekye I, Gyan BA, Adjei S, et al. Antiatherogenic and anti-ischemic potentials of Croton membranaceus observed during sub-chronic toxicity studies. Phcog Res 2013;5(1):10-6. https://doi. org/10.4103/0974-8490.105640; PMid:23598919 PMCid:PMC3579014.

14. Rodrigues GR, Di Naso FC, Porawski M, Marcolin E, Kretzmann NA, Ferraz $A B F$, et al. Treatment with aqueous extract from Croton cajucara Benth reduces hepatic oxidative stress in streptozotocin-diabetic rats. J Biomed Biotechnol 2012;2012:1-7. https://doi.org/10.1155/2012/902351; PMid:22811599 PMCid:PMC3395422.

15. Salatino A, Salatino MLF, Negri G. Tradicional uses, chemistry and pharmacology of Croton species (Euphorbiaceae). J Braz Chem Soc 2007;18(1):11-33 https://doi.org/10.1590/S0103-50532007000100002.

16. Veiga-Júnior VF, Pinto AC, Maciel MAM. Plantas medicinais: cura segura? Quím Nova 2008;28(3):519-28. https://doi.org/10.1590/S0100-40422005000300026.

17. Azevedo MMB, Almeida CA, Chaves FCM, Rodrigues IA, Bizzo HR, Alviano CS, et al. 7-hydroxycalamenene effects on secreted aspartic proteases activity and biofilm formation of Candida spp. Phcog Mag 2016;12(45):36-40. https://doi. org/10.4103/0973-1296.176022 ; PMid:27019560 PMCid:PMC4787334.

18. Randau KP, Florêncio DC, Ferreira CP, Xavier HS. Estudo farmacognóstico de Croton rhamnifolius H.B.K. e Croton rhamnifolioides Pax \& Hoffm. (Euphorbiaceae). Rev Bras Farmacogn 2004;14(2):89-96. https://doi.org/10.1590/S0102$695 \times 2004000200001$

19. Torres MCM, Assunção JC, Santiago GMP, et al. Larvicidal and nematicidal activities of the leaf essential oil of Croton regelianus. Chem \& Biodiv 2008;5(12):2724-8.https://doi.org/10.1002/cbdv.200890227; PMid:19089831.

20. Cartaxo SL, Souza MMA, Albuquerque UP. Medicinal plants with bioprospecting potential use in semi-arid northeastern Brazil. J Ethnopharmacol 2010;131 (2):326-42. https://doi.org/10.1016/j.jep.2010.07.003 ; PMid:20621178.
21. Monteiro JM, Ramos MA, Araújo EDL, Amorim ELC, Albuquerque UP. Dynamics of medicinal plants knowledge and commerce in an urban ecosystem (Pernambuco, Northeast Brazil). Environ Monitor Assessm 2011;178(1-4):179-202. https://doi.org/10.1007/s10661-010-1681-3 ; PMid:20853190.

22. Nogueira LM, Silva MR, Santos SM, Albuquerque JFC, Ferraz IC, Albuquerque TT, et al. Antinociceptive effect of the essential oil obtained from the leaves of Croton cordiifolius Baill. (Euphorbiaceae) in mice. Ev-Bas Comp Alt Med 2015;2015:1-7. https://doi.org/10.1155/2015/620865 ; PMid:25821494 PMCid:PMC4363708

23. Johansen DA. Plant microtechnique. New York: MacGraw-Hill; 1940.

24. Kraus JE, Arduin M. Manual básico de métodos em morfologia vegetal. Rio de Janeiro: EDUR; 1997.

25. Bukatsch F. Bemerkungen zur doppelfärbung Astrablau-Safranin. Mikrokosmos 1972;61:255.

26. Sass JE. Botanical microtechnique. 2nd Ed. Ames: lowa State College Press; 1951. https://doi.org/10.5962/bhl.title.5706.

27. Vasconcelos AL, Vasconcelos AL, Randau KP. Pharmacognostic characterization of Spondias mombin L. (Anacardiaceae). Pharmacogn J 2016;8(6):513-9. https:// doi.org/10.5530/pj.2016.6.1.

28. Metcalfe CR., Chalk L. Anatomy of the dicotyledons: leaves, stem, and wood in relation to taxonomy with notes on economic uses. Oxford: Clarendon Press, 1950.

29. Gales RC, Toma C. Comparative anatomy of the organs of some Euphorbia species (Euphobiaceae JUSS.) from the Romanian flora. Rom J Biol 2006-2007;5152:39-47.

30. Rudall P. Laticifers in vascular cambium and wood of Croton spp. (Euphorbiaceae). lawa Bulletin 1989;10(4):379-83. https://doi.org/10.1163/2294193290001127.

31. Randau KP, Xavier HS, Pinna GFAM, Albuquerque UP. Padronização botânica do Croton rhamnifolius H.B.K. e Croton rhamnifolioides Pax \& Hoffm. (Euphorbiaceae). Rev Bras Farm 2002;83(1/4):3-7.

32. Farías FR, Williamson JS, Rodriguez SV, Angeles G, Portugal VO. Bark anatomy in Croton draco var. draco (Euphorbiaceae). Am J Bot 2009:96(12):2155-67. https://doi.org/10.3732/ajb.0900035; PMid:21622332.

33. Hayden SM, Hayden WJ. Stem development, medullary bundles, and wood anatomy of Croton glandulosus var. septentrionalis (Euphorbiaceae). lawa 1994;15(1):51-63. https://doi.org/10.1163/22941932-90001342.

34. Franceschi VR, Nakata PA. Calcium oxalate in plants: formation and function. Annu Rev Plant Biol 2005;56(1):41-71. https://doi.org/10.1146/annurev.arplant.56.032604.144106 ; PMid:15862089.

35. Tadavil SC, Bhadane VV. Taxanomic significance of the rachis, petiole and petiolule anatomy in some Euphorbiaceae. Biolife 2014;2:850-7.

36. Sá-Haiad BS, Serpa-Ribeiro ACC, Barbosa CN, Pizzini D, Leal DO, Senna-Valle I, et al. Leaf structure of species from three closely related genera from tribe $\mathrm{CrO}$ toneae Dumort. (Euphorbiaceae s.s., Malpighiales). Plant Syst Evol 2009;283(34):179-202. https://doi.org/10.1007/s00606-009-0229-x

37. Mendonça MS, IIkiu-Borges F, Souza MC. Anatomia foliar de Croton cajucara Benth. (Euphorbiaceae) como contribuição ao estudo farmacognóstico de plantas da região amazônica. Rev Bras PI Med 2008;10(2):18-25.

38. Lucena MFA, Sales MF. Tricomas foliares em espécies de Croton L. (Crotonoideae-Euphorbiaceae). Rodriguésia 2006;57(1):11-25.

39. Aguiar MO, Preisinger H. Traits of leaf anatomy of Croton lanjouwensis Jablonski (Euphorbiaceae) in different strata of the plant. German-Brazilian Workshop on Neotropical Ecosystems - Achievements and Prospects of Cooperative Research Hamburg, 2000;3-8.

40. Luchi AE. Anatomia do lenho de raiz de Croton urucurana Baill. (Euphorbiaceae) de solos com diferentes níveis de umidade. Hoehnea 2004;31(3):243-50.

41. Luchi AE. Anatomia do lenho de Croton urucurana Baill. (Euphorbiaceae) de solos com diferentes níveis de umidade. Rev Bras Bot 2004;27(2):271-80. https:// doi.org/10.1590/S0100-84042004000200007. 


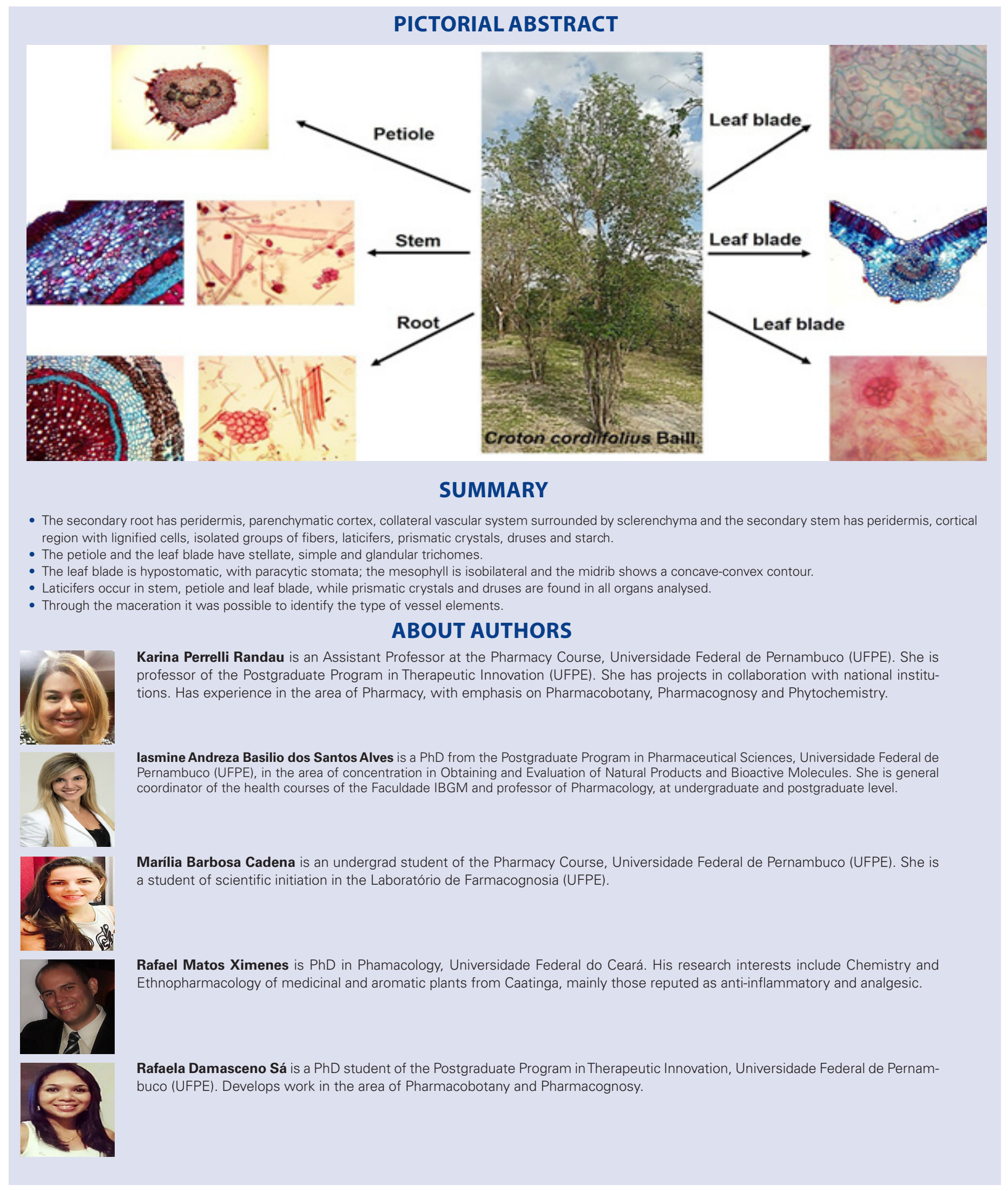

Cite this Article: Alves IABS, Sá RD, Cadena MB, Ximenes RM, Randau KP. Microscopic Characterization of Croton cordiifolius Baill. (Euphorbiaceae). Pharmacogn J. 2017;9(3):361-6. 